\title{
IMPLEMENTASI TRILOGI PENDIDIKAN KI HAJAR DEWANTARA UNTUK TENAGA PENDIDIK DI INDONESIA
}

\author{
Oleh: \\ Imelda Indah Kusumastita \\ Universitas Negeri Malang \\ Email: imeldaindah623@gmail.com
}

\begin{abstract}
Abstrak
Pendidikan merupakan proses yang dilalui sebagai bentuk peningkatan kualitas manusia. Dalam suatu negara peningkatan mutu pendidikan sangat penting. Jika mutu pendidikan suatu negara semakin berkembang maka kualitas manusia juga akan meningkat. Dalam proses mewujudkan tujuan pendidikan nasional dibutuhkan seorang pembimbing yang disebut sebagai guru atau tenaga pendidik. Tenaga pendidik merupakan seseorang yang memiliki peranan penting dalam proses kemajuan mutu pendidikan. Seorang tenaga pendidik harus memiliki banyak kemampuan, selain itu tenaga pendidik juga harus memiliki sikap tauladan yang baik untuk peserta didiknya (Leonard, 2015). Trilogi pendidikan Ki Hajar Dewantara merupakan sebuah semboyan pendidikan yang dicetuskan oleh beliau. Semboyan ini tidak hanya berupa semboyan, tetapi memiliki makna yang begitu mendalam terutama bagi pendidikan di Indonesia. Dengan adanya penerapan trilogi pendidikan Ki Hajar Dewantara untuk tenaga pendidik ini diharapkan kualitas pendidik di Indonesia semakin baik, sehingga mutu pendidikan di Indonesia juga lebih meningkat di setiap tahunnya.
\end{abstract}

\section{Kata Kunci: Pendidikan, Tenaga Pendidik, Ki Hajar Dewantara}

\section{PENDAHULUAN}

Pendidikan adalah unsur terpenting dalam menjalankan suatu kehidupan. Sejak kecil seseorang sudah mendapatkan pendidikan awal yaitu pendidikan dengan lingkup keluarga. Pendidikan merupakan unsur utama untuk kemajuan suatu bangsa. Kemajuan suatu bangsa berkaitan dengan mutu pendidikan dari bangsa tersebut. Pendidikan dapat dikatakan bermutu apabila pendidikan tersebut memiliki kemampuan untuk pengembangan potensi kearah positif yang biasanya terpendam dalam diri seorang peserta didik. Dengan adanya pendidikan yang lebih bermutu maka akan dihasilkan seseorang tenaga yang lebih berpotensial dan tangguh dan di harapkan lebih siap untuk bersaing dengan masyarakat tingkat dunia. Pendidikan merupakan suatu komponen penting dalam menghasilkan sumber daya manusia yang lebih bermutu. Pendidikan adalah proses sistematis dalam peningkatan martabat manusia (Widodo, 2015). Pendidikan memang sangat penting bagi suatu bangsa, dapat dilihat dari kemjajuan dunia barat seperti Amerika dan 
Eropa, dua negara tersebut merupakan salah satu negara yang menjadi panutan jika sudah berbicara tentang pendidikan. Hal tersebut dapat diketahui melalui berbagai data yang berisi mengenai keunggulan bidang pendidikan negara tersebut terutama dalam hal model pembelajaran, tenaga pendidik, dan juga hasil dari pendidikan tersebut yang berupa produk lulusan atau sumber daya manusia yang memiliki potensial tinggi dalam berkarir dan mampu bersaing dalam tingkat dunia. Sedangkan untuk bangsa Indonesia sendiri masih dikatakan sebagai negara berkembang yang masih mencari jalan untuk menjadi negara maju terutama dalam bidang pendidikan. Sistem pendidikan yang ada di Indonesia masih memiliki acuan pada Pendidikan Nasional yang dipercaya membawa kemajuan dan perkembangan bangsa dan menjawab tantangan zaman. Dalam Pasal 1 UU SISDIKNAS No. 20 tahun 2003 dikatakan bahwa Sistem Pendidikan Nasional adalah semua komponen pendidikan yang memiliki keterkaitan secara terpadu untuk mencapai tujuan pendidikan nasional (Munirah, 2015).

Permasalahan pendidikan yang telah dihadapi oleh Indonesia saat ini tidak hanya untuk mengupayakan pendidikan yang mudah diakses oleh masyarakat, akan tetapi juga untuk memperbaiki dan meningkatkan kualitas pendidikan di Indonesia. Kualitas pendidikan dalam suatu bangsa tidak lain ditentukan oleh kualitas tenaga pendidiknya. Seorang tenaga pendidik harus memiliki kompetensi dan kualifikasi yang memenuhi standar nasional pendidikan (Arifa \& Prayitno, 2019). Seorang tenaga pendidik adalah unsur terdepan yang akan menentukan kemajuan mutu pendidikan dalam suatu bangsa. Seorang tenaga pendidik yang lebih kompeten dapat menjamin perbaikan kualitas sumber daya manusia dalam sebuah negara. Tenaga Pendidik memang dituntut untuk dapat memiliki kemampuan yang luar biasa untuk membuat ketertarikan peserta didik dalam proses pembelajaran yang berlangsung. Seorang tenaga pendidik dapat dikatakan sebagai garda paling depan untuk kemajuan bangsa Indonesia. Waktu efektif seorang peserta didik lebih banyak di habiskan di lingkungan sekolah, maka dari itu peranan guru sangat penting dalam proses pendidikan di lingkungan sekolah tersebut. Seorang guru juga diharapkan dapat membawa peserta didiknya menjadi lebih bersemangat dalam memperoleh pendidikan. Selain itu, seorang tenaga pendidik juga harus memiliki tingkah laku yang baik karena mereka akan dijadikan sebagai panutan oleh peserta didiknya. Kompetensi seorang guru terbagi menjadi 4 bagian, yaitu pedagogik, profesional kerja, kepribadian, dan juga sosial. Empat kompetensi tersebut merupakan kompetensi yang komponen-komponennya harus dimiliki oleh seorang tenaga 
pendidik. Misalnya dalam hal kepribadian, seorang pendidik harus memiliki kepribadian yang baik, kepribadian yang baik maksudnya kepribadian yang tidak membawa contoh buruk bagi peserta didiknya. Seorang pendidik merupakan contoh tauladan untuk peserta didik, apapun yang dilakukan oleh tenaga pendidik akan menjadi contoh untuk peserta didiknya (Leonard, 2015).

Terkait dengan kompetensi tenaga pendidik di Indonesia saat ini, masih banyak tenaga pendidik yang belum memenuhi kriteria kompetensi yang seharusnya dimiliki oleh seorang tenaga pendidik. Kualitas tenaga pendidik di Indonesia masih berada dalam taraf biasa saja. Saat ini masih banyak tenaga pendidik yang mengesampingkan kompetensi sebagai seorang tenaga pendidik, salah satunya dalam kompetensi profesional kerja dan kepribadian. Tenaga pendidik saat ini kebanyakan kurang perduli terhadap kepribadian mereka sebagai tenaga pendidik yang merupakan contoh untuk peserta didiknya, padahal kompetensi tersebut adalah komponen yang sangat penting yang harus dimiliki oleh seorang tenaga pendidik. Trilogi pendidikan Ki Hajar Dewantara yang berbunyi "Ing Ngarso Sung Tulodho, Ing Madya Mangun Karsa, Tut Wuri Handayani" perlu dikembangkan sebagai suatu pedoman agar dapat mempengaruhi kedisiplinan seorang tenaga pendidik dan menjadikan tenaga pendidik lebih menyadari akan tanggung jawabnya menjadi seorang pendidik yang memang memiliki tanggung jawab besar. Seorang tenaga pendidik diharapkan dapat menjadi seorang yang dapat dijadikan tauladan yang baik untuk peserta didiknya (Wicaksono, 2019). Dari masalah-masalah mengenai tenaga kependidikan tersebut, penulis akan membahas lebih dalam mengenai bagaimana konsep dari Trilogi Pendidikan Ki Hajar Dewantara, bagaimana kualitas tenaga pendidik di Indonesia, dan bagaimana pengimplementasian Trilogi Pendidikan Ki hajar Dewanatara untuk tenaga pendidik.

\section{METODE PENELITIAN}

Dalam proses penulisan artikel penulis mengumpulkan data dengan menggunakan metode penulisan Library Research yaitu penelitian yang berdasarkan sumber pustaka seperti buku ataupun artikel, jurnal yang ada di Internet. Kegiatan pengumpulan data dilakukan secara sistematis untuk mengumpulkan, mengolah, dan juga menyimpulkan data guna untuk mencari jawaban atas permasalahan yang dihadapi ketika proses penulisan artikel berlangsung (Sari \& Asmendri, 2020).

\section{HASIL DAN PEMBAHASAN}

\section{Konsep Trilogi Pendidikan Ki Hajar Dewantara}

Ki Hajar Dewantara adalah salah satu pejuang yang terlibat dalam pergerakan kemerdekaan 
Indonesia. Beliau lahir pada tanggal 2 Mei dan saat ini diperingati sebagai Hari Pendidikan Nasional di Indonesia. Ki Hajar Dewantara merupakan salah satu tokoh pendidikan di Indonesia yang memiliki beberapa pemikiran tentang pendidikan. Salah satu diantara pemikirannya yaitu tentang konsep pendidikan jiwa merdeka. Dalam konsep tersebut mengandung nilainilai yang sangat penting dalam membangun kualitas sumber daya manusia Indonesia untuk kedepannya (Hendratmoko,dkk. 2017:152-153).

Menurut Ki Hajar Dewantara pendidikan merupakan hal yang sangat penting dalam kehidupan. Pendidikan merupakan sebuah kunci untuk membangun sebuah bangsa agar terus berkembang. Beliau juga mengungkapkan bahwa belajar harus memiliki kesesuaian dengan cipta, rasa, dan karsa (Mujito, 2014:68). Dalam suatu pembelajaran atau pendidikan tidak akan terlepas dari adanya tujuan pendidikan. Menurut Ki Hajar Dewantara pendidikan merupakan tuntunan di dalam hidup seseorang. Tujuan pendidikan yang paling utama bagi Ki Hajar Dewantara adalah memerdekakan manusia. Merdeka dalam artian merdeka secara fisik, mental, dan rohani. Menurut Ki Hajar Dewantara pendidikan merupakan suatu tuntunan, tuntunan disini berarti bahwa pendidikan akan membawa seseorang ke titik terang, lebih maju, dan lebih mengerti akan arti hidup. Kemerdekaan pribadi dibatasi oleh tertib damai kehidupan bersama, dan juga mendukung sikap-sikap seperti keselarasan, kekeluargaan, musawarah, toleransi, kebersamaan, demokrasi, tanggung jwab, dan disiplin. Menurut Ki Hajar Dewantara seorang individu adalah makhuk hidup yang bisa berkembang melalui kodrat yang telah dimiliki oleh orang tersebut (Mujito, 201470).

Tujuan pendidikan dari pemikiran Ki Hajar Dewantara menurut Kuswandi (2005:298) dalam Hendratmoko, dkk (2017:153-154) adalah menjadikan kehidupan anak, lahir, dan batin menjadi merdeka. Teori jiwa merdeka menurut $\mathrm{Ki}$ Hajar Dewantara memiliki pandangan bahwa tujuan pendidikan pada hakikatnya merupakan memerdekakan hidup dan kehidupan anak lahir maupun batin. Seseorang yang memiliki jiwa yang merdeka maka kehidupannya juga akan ikut merdeka. Jiwa merdeka yang dimaksudkan disini yaitu jiwa yang bersih, selalu memiliki pikiran yang positif, memiliki perasaan yang indah dan memiliki kemauan yang mulia.

Ki Hajar Dewantara tidak dapat terlepas dari perjalanan pendidikan di Indonesia.. Ki Hajar Dewantara juga merupakan pelopor sistem pendidikan yang ada di Indonesia. Beliau juga telah mendirikan perguruan Taman Siswa sebagai bentuk perlawanan terhadap penjajahan Belanda. Pemikiran Ki Hajar Dewantara memiliki relevansi 
tinggi untuk terobosan untuk membangun pendidikan saat ini yang sedang dalam keadaan yang tidak baik-baik saja. Ki Hajar Dewantara juga memiliki semboyan yang terkenal yang biasanya disebut sebagai Trilogi Pendidikan. Trilogi Pendidikan tersebut yaitu Ing Ngarsa Sung Tuladha (di depan memberi teladan), Ing Madya Mangun Karsa (di tengah menciptakan peluang untuk berprakarsa), Tut Wuri Handayani (di belakang memberi dorongan). Tut Wuri Handayani sendiri menjadi slogan Departemen Pendidikan Nasional (Susilo, 2018).

Adapun makna Trilogi Pendidikan Ki Hajar Dewantara menurut Wulandari (2017) adalah sebagai berikut:

\section{Ing Ngarsa Sun Tuladha}

Ing Ngarsa memiliki arti yang didepan, sedangkan Sun merupakan kata singkat dari Insun yang memiliki arti aku atau saya, selanjutnya Tuladha dapat diartikan contoh atau tauladan. Maka arti dari Ing Ngarsa Sun Tuladha adalah didepan menjadi contoh atau tauladhan. Dari semboyan tersebut Ki Hajar Dewantara memberikan gambaran bahwa menjadi seorang pemimpin atau tenaga pendidikan tidak hanya untuk semata-mata menjadi seorang pemimpin saja tetapi harus memiliki kepribadian yang baik agar dapat dijadikan sebagai tauladan yang baik untuk orang-orang yang berada di sekitarnya.

\section{Ing Madya Mangun Karsa}

Ing Madya memiliki arti yang ditengah, Mangun memiliki arti bangkit atau membangkitkan, sedangkan Karsa dapat diartikan sebagai suatu bentuk kemauan atau niat. Jadi Ing Madya Mangun Karsa dapat diartikan di tengah membangkitkan niat. Dari arti tersebut dapat dikatakan bahwa ketika seseorang berada di tengahtengah kegiatan atau kesibukan harus juga memiliki kemampuan untuk dapat membangkitkan semangat. Seseorang harus memiliki kemampuan untuk memberikan inovasi baru dilingkungannya dengan cara menciptakan suasana baru yang membuat orang lain lebih nyaman.

\section{Tut Wuri Handayani}

Tut Wuri berarti mengikuti dari belakang dan Handayani memiliki arti memberikan dorongongan. Tut Wuri Handayani dapat diartikan dari belakang memberi dorongan. Disini maksud dari semboyan tersebut yaitu dari belakang kita harus memberikan dorongan atau semangat moral. Adanya semangat moral menjadikan seseorang lebih termotivasi, jadi adanya dorongan semangat moral ini sangat dibutuhkan. Semboyan ini memiliki tujuan untuk menciptakan pribadi yang lebih mandiri dan juga tidak memiliki ketergantungan kepada orang lain. Diharapkan dapat menciptakan generasi baru yang lebih kompeten.

\section{Keadaan Tenaga Pendidik Di Indonesia}


Dalam proses peningkatan mutu pendidikan nasional, maka peran seorang tenaga pendidik sangat penting. Tenaga pendidik yang diperlukan yaitu tenaga pendidik yang memiliki standard mutu kompetensi dan profesionalitas yang sudah terjamin. Profesionalitas seorang tenaga pendidik sagat dibutuhkan. Mengingat proses pembangunan pendidikan itu sangat berat, maka dilakukan upaya-upaya yang dapat mendorong dan memberdayakan tenaga pendidik agar semakin memiliki tanggung jawab kerja dan progesionalitas kerja. Profesionalitas tenaga pendidik yang ada di Indonesia dianggap masih sangat kurang dan belum memadai. Banyak terjadi tenaga pendidik yang sangat kurang memiliki profesionalitas salah satu contohnya dalam hal telat ketika masuk sekolah. Sebenarnya ini bukan masalah sepele, hal inilah yang akan memicu kontra antara tenaga pendidik dengan siswa. Jika seorang tenaga pendidiknya saja sudah tidak bisa tepat waktu atau seenaknya sendiri, maka kebanyakan peserta didiknya pun juga mengikuti apa yang telah dilakukan oleh tenaga pendidik tersebut (Mustofa, 2007).

Menurut Danim (2002:23)

dalam Fahdini, dkk (2014:35) profesionalisme memiliki arti yaitu komitmen para anggota suatu profesi untuk meningkatkan kemampuan profesionalnya dan akan terus menerus berkembang strategi yang akan digunakan dalam proses melakukan pekerjaan yang sesuai dengan profesinya. Hal ini menjadikan seorang tenaga pendidik yang profesional akan senantiasa berusaha mengupayakan agar kualitas diri semakin meningkat. Profesionalisme seorang tenaga pendidik memang sangat penting dalam proses pembelajaran berlangsung. Seorang tenaga pendidik yang profesional merupakan tenaga pendidik yang memiliki keahlian sesuai dengan mutu pendidikan, selain itu tenaga pendidik harus memiliki rasa tanggung jawab yang besar untuk peserta didiknya. Akan tetapi, tidak semua tenaga pendidik memiliki sikap profesional tinggi. Masih banyak tenaga pendidik yang melanggar kewajibannya menjadi seorang pendidik.

Beberapa permasalahan yang sering terjadi dalam proses pendidikan yaitu terkait dengan tenaga pendidik yang kurang memiliki sikap disiplin, dan yang sering terjadi yaitu dalam hal keterlambatan, tingkah laku dan sikap seorang tenaga pendidik di sekolah. Hal ini dinyatakan bahwa tenaga pendidik tidak profesional dalam menjalankan peraturan dan kewajiban yang harus dilakukan sebagai seorang tenaga pendidik. Selain itu, sekarang ini banyak terjadi seorang tenaga pendidik yang tiba-tiba ijin meninggalkan kelas atau ijin pulang dengan alasan tertentu dan meninggalkan peserta didiknya ketika proses pembelajaran 
masih berlangsung. Hal tersebutlah yang akhirnya mendorong peserta didik juga tidak disiplin, tujuan pendidikan tidak tercapai, dan motivasi belajar siswa juga berkurang. Menjadi seorang tenaga pendidik seharusnya memiliki tanggung jawab untuk menunjang motivasi belajar peserta didik agar pendidikan yang didapat juga semakin berkembang. Untuk mengurangi ketidakdisiplinan seorang tenaga pendidik tersebut maka seorang pendidik tersebut harus diberikan kesadaran, tanggung jawab, kepedulian, dan komitmen agar mereka tidak seenaknya sendiri. Seorang pendidik merupakan seorang yang menjadi pemimpin bagi peserta didiknya. Sebagai seorang pemimpin seharusnya perlu menuntun, mengarahkan, dan berjalan didepan untuk membangun pendidikan yang lebih baik

\section{Implementasi Trilogi Pendidikan Ki Hajar Dewantara untuk Tenaga Pendidik di Indonesia}

Trilogi Pendidikan Ki

Hajar Dewantara masih sangat populer dan masih menjadi slogan pendidikan nasional Indonesia hingga saat ini. Konsep tersebut memiliki makna yang sangat mendalam. Dengan adanya konsep tersebut dapat dijadikan sebagai pedoman untuk meningkatkan kualitas tenaga pendidik yang ada di Indonesia. Tenaga pendidik di Indonesia harus mengalami kemajuan disetiap tahunnya, karena komponen utama dalam kemajuan suatu bangsa adalah Tenaga Pendidik. Berikut merupakan implementasi dari Trilogi Pendidikan Ki Hajar Dewantara untuk tenaga pendidik di Indonesia:

a) Ing Ngarsa Sung Tulodho

Menjadi seorang tenaga pendidik memang tidak mudah. Seorang tenaga pendidik harus memiliki kepribadian dan tingkah laku yang baik, karena seorang tenaga pendidik akan menjadi contoh tauladan yang baik untuk peserta didiknya. Menjadi tauladan yang baik merupakan hal yang sangat penting bagi seorang tenaga pendidik. Hal ini akan berpengaruh pada kepercayaan peserta didik kepada seorang pendidik tersebut. Tenaga pendidik diharapkan mampu menarik perhatian peserta didik agar mereka dapat menjadikan seorang pendidik sebagai tauladan yang baik bagi mereka. Semboyan ini jika diimplementasikan juga dapat memiliki arti bahwa seorang tenaga pendidik itu akan menjadi sosok panutan bagi peserta didik ataupun orang-orang disekitarnya yang membutuhkan didikan dari tenaga pendidik tersebut. Tenaga pendidik menjadi contoh panutan yang baik lewat tingkah laku dan perbuatan yang telah dilakukannya dalam proses pendidikan berlangsung. Sikap teladan dari seorang tenaga pendidik merupakan suatu hal yang paling utama dalam proses pendidikan. Segala sesuatu yang telah dilakukan oleh tenaga pendidik 
tersebut harus dapat dipertanggung jawabkan. Tingkah laku tenaga pendidik kebanyakan akan di tiru oleh peserta didiknya atau oleh seseorang yang berada di bawahnya. Seorang pendidik harus menjadi contoh tauladan yang baik untuk peserta didiknya (Wicaksono, 2019).

\section{b) Ing Madya Mangun Karsa}

Seorang tenaga pendidik tidak akan bisa berdiri sendiri dalam menjalankan proses pendidikan. Seorang pendidik harus bisa bekerjasama dengan peserta didiknya untuk mencapai tujuan pembelajaran. Hal inilah yang nantinya akan mempermudah tercapainya proses pendidikan. Seorang tenaga pendidik harus bisa menyatu dengan peserta didiknya, menyatu disini yaitu berbaur atau saling bertukar pendapat. Jadi dalam proses pembelajaran tidak hanya seorang pendidik saja yang bersikap aktif, tetapi peserta didiknya pun juga harus diberikan kesempatan untuk menyampaikan pendapatnya. Darisinilah diharapkan seorang pendidik dapat menyatu dengan peserta didiknya, dan peserta didiknya pun juga dapat merasa nyaman dengan pembelajaran yang sedang berlangsung. Dengan adanya kerjasama yang baik antara tenaga pendidik dengan peserta didik maka tujuan pendidikan akan dengan mudah dicapai. Semboyan ini memang memiliki arti ditengah membangunkan niat, jika tenaga pendidik lebih bisa bergabung dan bekerjasama dengan peserta didik maka diharapkan peserta didik juga dapat terbangun niatnya untuk lebih giat belajar agar tujuan pendidikan juga dapat tercapai (Wicaksono, 2019).

c) Tut Wuri Handayani

Dari adanya semboyan tersebut dapat diimplementasikan bahwa seorang tenaga pendidik harus bisa memberikan dorongan kepada peserta didiknya. Seorang tenaga pendidik harus bisa memberikan motivasi belajar kepada peserta didiknya agar peserta didiknya dapat belajar dengan benar. Terkadang peserta didik memiliki kecenderungan malas dan bosan untuk belajar, dari masalah tersebut sudah menjadi tugas pendidik agar bisa mendorong peserta didik untuk lebih maju. Menjadi seorang tenaga pendidik harus bisa menjadi motivator bagi peserta didiknya. Semboyan ini juga dapat mendorong seorang pendidik agar lebih maju dalam berlangsungnya proses pendidikan. Lebih maju disini memiliki arti bahwa seorang tenaga pendidik harus bisa menjadi lebih kreatif dan selalu menemukan inovasi baru sebagai bahan untuk proses berlangsungnya pembelajaran. Jika seorang pendidik memiliki dorongan motivasi tinggi dan selalu kreatif maka peserta didiknya juga akan ikut memiliki kreatifitas tinggi dan motivasi belajar mereka juga akan terdorong lebih kuat. Seorang tenaga pendidik juga harus bisa menjadi penyemangat untuk peserta didiknya dalam proses pembelajaran berlangsung agar mereka memiliki pemikiran yang lebih terbuka. Jika 
peserta didik memiliki pemikiran yang lebih terbuka, dan tidak malu untuk menyampaikan pendapat maka minat belajar mereka juga akan meningkat dengan cepat. Hal inilah yang dimaksudkan bahwa seorang tenaga pendidik harus bisa menjadi motivator, penyemangat, dan juga pendorong minat belajar peserta didiknya (Wicaksono, 2019).

\section{KESIMPULAN}

Pendidikan merupakan unsur utama untuk kemajuan suatu bangsa. Kemajuan suatu bangsa berkaitan dengan mutu pendidikan dari bangsa tersebut. Pendidikan dapat dikatakan bermutu apabila pendidikan tersebut memiliki kemampuan untuk pengembangan potensi kearah positif yang biasanya terpendam dalam diri seorang peserta didik. Tenaga pendidik adalah unsur terdepan yang akan menentukan kemajuan mutu pendidikan dalam suatu bangsa. Seorang tenaga pendidik yang lebih kompeten dapat menjamin perbaikan kualitas sumber daya manusia dalam sebuah negara. Dalam proses pengembangan kemajuan tenaga pendidik maka di gunakan Trilogi Pendikan Ki Hajar Dewantara sebagai pedoman bagi tenaga pendidik. Trilogi Pendidikan tersebut yaitu Ing Ngarsa Sung Tuladha (di depan memberi teladan), Ing Madya Mangun Karsa (di tengah menciptakan peluang untuk berprakarsa), Tut Wuri Handayani (di belakang memberi dorongan). Trilogi Pendidikan Ki Hajar
Dewantara masih sangat populer dan masih menjadi slogan pendidikan nasional Indonesia hingga saat ini. Konsep tersebut memiliki makna yang sangat mendalam. Dengan adanya konsep tersebut dapat dijadikan sebagai pedoman untuk meningkatkan kualitas tenaga pendidik yang ada di Indonesia.

\section{DAFTAR PUSTAKA}

Fahdini, d. (2014). Identifikasi Kompetensi Guru Sebagai Cerminan Profesionalisme Tenaga Pendidikdi Kabupaten Sumedang. Jurnal Mimbar Sekolah Dasar, Vol.1 No. 1, 33-42.

Hendratmoko, T., Kuswandi, D., \& Setyosari, P. (2017). Tujuan Pembelajaran Berlandaskan Konsep Pendidikan Jiwa Merdeka Ki Hajar Dewantara. Jurnal Inovasi dan Teknologi Pembelajaran, Vol. 3 No. 2, 152-157.

Leonard. (2015). Kompetensi Tenaga Pendidik Di Indonesia: Analisis Dampak Rendahnya Kualitas Sdm Guru Dan Solusi Perbaikannya. Jurnal Formatif, Vol. 5 No. 3, 192201.

Megawanti, P. (2012). Meretas Permasalahan Pendidikan Di Indonesia. Jurnal Formatif, Vol. 2 No. 3, 227-234.

Mujito, W. E. (2014). Konsep Belajar Menurut Ki Hadjar Dewantara dan Relevansinya Dengan Pendidikan Gama 
Islam. Jurnal Pendidikan Agama Islam, Vol. 9 No. 1, 65-78.

Munirah. (2015).

SISTEM

PENDIDIKAN

DI

INDONESIA:

Antara

Keinginan Dan Realita.

Jurnal Auladuna, Vol. 2 No.

2, 233-245.

Mustofa.

(2007).

Upaya

Pengembangan

Profesionalisme Guru Di

Indonesia. Jurnal Ekonomi \&

Pendidikan, Vol. 4 No. 1, 76-

88.

Prayitno, U. S., \& Arifa, F. N. (2019). Peningkatan Kualitas Pendidikan: Program

Pendidikan Profesi Guru

Prajabatan Dalam

Pemenuhan Kebutuhan Guru

Profesional Di Indonesia.

Jurnal Masalah Sosial, Vol. 10 No. 1, 1-17.

Sari, M., \& Asmendri. (2020).

Penelitian Kepustakaan

(Library Research) dalam

Penelitian Pendidikan IPA.

Jurnal Penelitian, Vol. 6 No.

1, 41-53.

Susilo, S. V. (2018). Refleksi Nilai-

Nilai Pendidikan Ki Hadjar

Dewantara Dalam Upaya

Upaya Mengembalikan Jati

Diri Pendidikan Indonesia.

Jurnal Cakrawala Pendas,

Vol. 4 No. 1, 33-41.

Wicaksono, A. F. (2019).

Implementasi Trilogi $\mathrm{Ki}$

Hajar Dewantara dalam

Kepemimpinan Kepala

Sekolah sebagai Upaya
Meningkatkan Kedisiplinan

Guru di SMK Taman Siswa 1

Imogiri Yogyakarta. Jurnal

Keislaman

dan

Kemasyarakatan, Vol. 3 No.

1, 53-71.

Widodo, H. (2015). Potret Pendidikan Di Indonesia Dan Kesiapannya Dalam Menghadapi Masyarakat Ekonomi Asia (Mea). Jurnal Cendekia, Vol. 13 No. 2, 294-307.

Wulandari, W. C. (2017).

Implementasi Trilogi $\mathrm{Ki}$

Hadjar Dewantara Dalam

Kepemimpinan Kepala

Sekolah Di Sd Negeri 1

Mergowati Kecamatan Kedu

Kabupaten Temanggung.

Retrieved Oktober 12, 2020, from

http://repository.upy.ac.id/16

80/1/ARTIKEL\%20JURNAL .pdf

Yanuarti, E. (2017). Pemikiran Pendidikan Ki. Hajar Dewantara Dan Relevansinya Dengan Kurikulum 13. Jurnal Penelitian, Vol. 11 No. 2, 237-266. 